\section{Achyranthes coynei Santapau, 1949 (Amaranthaceae) - an addition to the flora of Karnataka, India}

\author{
Sandeep R. Pai ${ }^{1}$, Vinayak Upadhya ${ }^{2}$, Harsha V. \\ Hegde $^{3}$ \& Sanjiva D. Kholkute ${ }^{4}$
}

1,2,3,4 Regional Medical Research Centre (RMRC), Indian Council of Medical Research (ICMR), Nehru Nagar, Belgaum, Karnataka 590010, India

${ }^{4}$ National Institute for Research in Reproductive Health, Jehangir Merwanji Street, Parel, Mumbai, Maharashtra 400012, India

Email: ${ }^{1}$ sandeeprpai@rediffmail.com, ${ }^{2}$ sirsivinayak@yahoo.com, ${ }^{3}$ harshavh@rediffmail.com (corresponding author),

${ }^{4}$ sankhol@yahoo.com

During exploratory surveys for medicinal plants from the Western Ghats of Belgaum region, an interesting plant species belonging to the genus Achyranthes (Amaranthaceae) was collected. After critical investigation, it was identified as Achyranthes coynei Santapau, 1949. The voucher specimens have been deposited at the Herbaria of Regional Medical Research Centre (RMRC), Belgaum.

The family Amaranthaceae is circumscribed with 850 species belonging to 71 different genera worldwide, out of which India is endowed with 60 species under 20 genera and an infraspecific taxa (Mishra \& Singh

Date of publication (online): 26 June 2011

Date of publication (print): 26 June 2011

ISSN 0974-7907 (online) | 0974-7893 (print)

Editor: Gopalakrishna Bhat

\section{Manuscript details:}

Ms \# 02685

Received 27 January 2011

Final revised received 24 May 2011

Finally accepted 06 June 2011

Citation: Pai, S.R., V. Upadhya, H.V. Hegde \& S.D. Kholkute (2011) Achyranthes coynei Santapau, 1949 (Amaranthaceae) - an addition to the flora of Karnataka, India. Journal of Threatened Taxa 3(6): 1875-1879.

Copyright: (c) Sandeep R. Pai, Vinayak Upadhya, Harsha V. Hegde \& Sanjiva D. Kholkute 2011. Creative Commons Attribution 3.0 Unported License. JoTT allows unrestricted use of this article in any medium for non-profit purposes, reproduction and distribution by providing adequate credit to the authors and the source of publication.

Acknowledgements: First author (SRP) gratefully acknowledges ICMR New Delhi for financial support in the form of post doctoral fellowship. Authors are indebted to Dr. Gopalkrishna Bhat, Udupi and Dr. Vinod B. Shimpale, Kolhapur for their valuable suggestions. The comments by Botanical Survey of India, Western Circle, Pune is duly acknowledged Thanks are due to Mr. Vasanta Kahalkar for providing the literature.

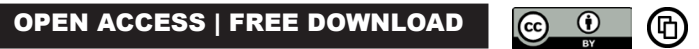

2001). The genus Achyranthes has about 15 species distributed in tropical and subtropical regions in the world (Shu 2003) of which 2 species (A. aspera L. and A. bidentata Blume) have been reported from Karnataka, India (Sharma et al. 1984).

Achyranthes coynei was first reported by Santapau in 1949 from Khandala, Maharashtra (Santapau 1949). Subsequently, the species was recorded from Raigad, Sindhudurg, Thane and Amaravati districts of Maharashtra, making it endemic to Maharashtra State (Singh et al. 2000; Mishra \& Singh 2001). This species was categorized as rare in the Red Data Book of Indian Plants (Sharma \& Kulkarni 1987) and in ENVIS Centre on floral diversity (2009) and as endangered by Mishra \& Singh (2001). The species was earlier reported only from four locations in Maharashtra State, with an estimated distribution range of ca. $5,000 \mathrm{~km}^{2}$ (Mishra \& Singh 2001). The present investigation reports the extended distribution of $A$. coynei to Karnataka State. The repeated random sampling during the present study, resulted in the recording of this plant at three different localities, namely Madanabhavi of Bailhongal Taluka, Pachapur and Godachinmalki of Hukkeri Taluka in Belgaum District along the road side and on canal bunds.

The collected specimens have been identified with the help of 'Flora of Maharashtra State' (Singh et al. 2000) and confirmed with the original description of the plant in 'Flora of Khandala' (Santapau 1967). The detailed descriptions of the plant with photographs are provided to enable its easy identification (Image $1 \mathrm{a}-\mathrm{h}$ and Image 2).

\section{Achyranthes coynei Santapau, 1949}

Sant. in Kew Bull. 1948: 488. 1949 et in Rec. Bot. Surv. India 16 (1), F1. Khandala 224. 1967 (3 ${ }^{\text {rd }}$ Rev. ed.); Raghavan \& Singh in Jain \& Sastry (eds.), Pl. Cons. Bull. 3:4. 1983 et in J. Econ. Tax. Bot. 5 (1): 161. 1984; Singh \& Raghavan ibid. 8(1): 34. 1986; Sharma \& Kulkarni in Nayar \& Sastry (eds.), Red Data Book Indian Pl. 2: 8, f. 1987; Almeida in J. Econ. Taxa. Bot. Addl. Ser. 8 (1), Fl. Savantwadi 1; 351. 1990; Kothari \& Moorthy, Fl. Raigad 338, 1993; Almeida Fl Maharashtra 2: 194, 1996; Anon., India Glob. Threat. Taxa 2. 1996; Yadav in Pokle et al. (eds.), 

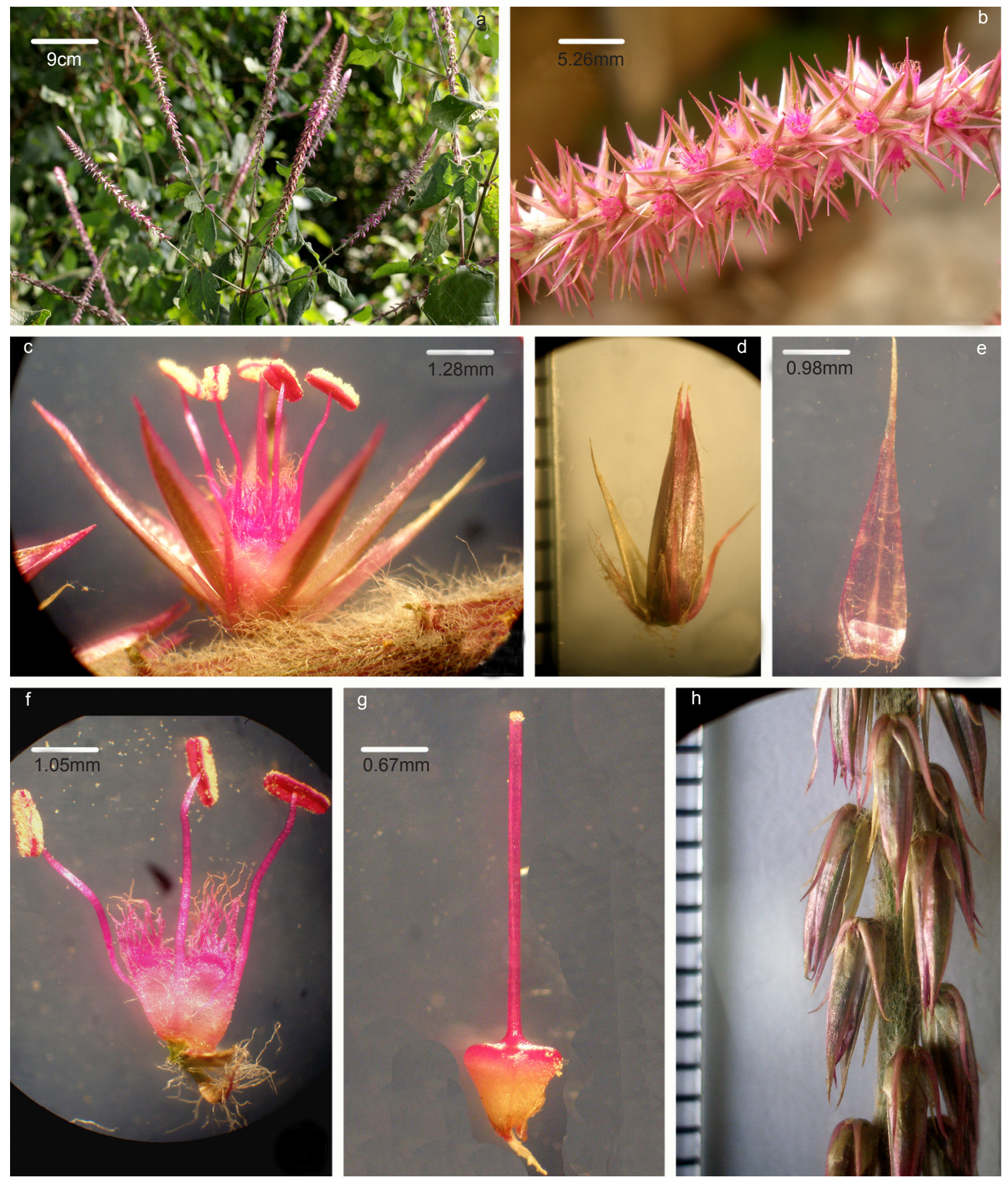

Image 1. Achyranthes coynei Santapau (Amaranthaceae).

a - habit; b - inflorescence; c - flower; $d$ - flower bud; e - bract; $f$ - androecium; $g$ - gynoecium; $h$ - fruits

Flow. Pl. Syst. Diver. Pt. 1: 44. 1997. Singh et al. Fl. Maharashtra State. Dicot Vol.2 779, 2000. Mishra \& Singh End. Threat. Fl. Pl. MH. 196, 2001. Uttarani, Kempu Uttarani (Kannada), Lal Aghada (Marathi).

Material examined: 10.xii.2010 and 03.i.2011, Godachinmalki, Pachapur and Madanabhavi in Belgaum District, Karnataka, India, coll. Sandeep Pai, Vinayak Upadhya and Harsha Hegde (RMRC 784,
$785 \& 790)$.

A perennial, profusely branching shrub, sub-erect, 2-4.5 m high. Stem terete, branches many, woody, younger ones pubescent, green or with purple patches, older ones glabrous or glabrescent, brown to purple in colour; nodes swollen. Leaves deciduous; dimorphic, lower ones big 15-23 x 7-10 cm; upper leaves gradually decreases in size, elliptic or lanceolate, 

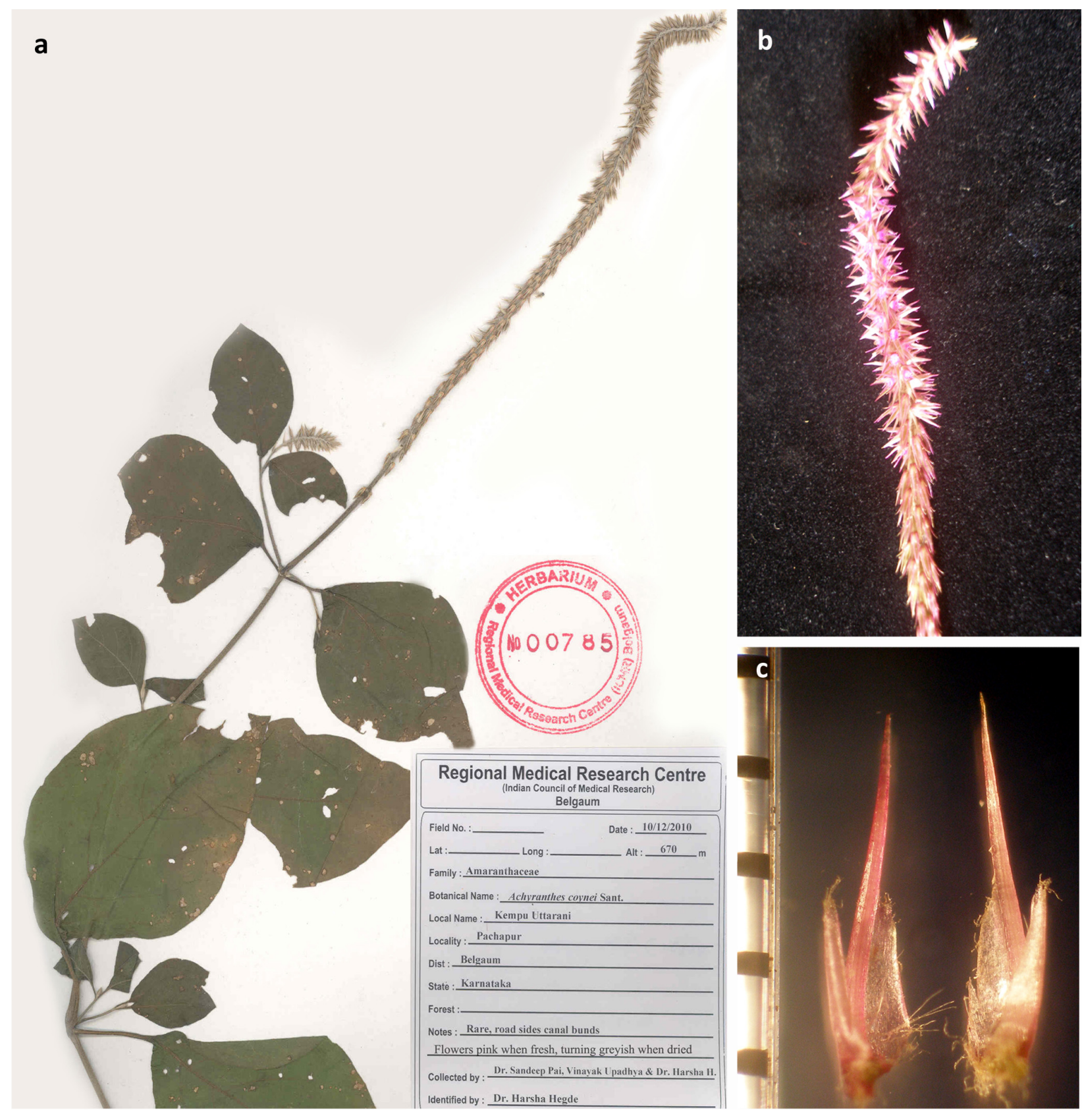

Image 2. a - Herbarium of Achyranthes coynei; b - Inflorescence: Flowers first erect, later patent, finally deflexed and appressed to the rachis; $\mathrm{c}$ - Bractioles.

acute or acuminate; subglabrous above, pubescent beneath especially on the mid rib, primary nerves and margins; margins entire; petiole 1-3 cm long, channeled, pink above, green beneath. Flowers in spikes, densely arranged on rachis; rachis thick, 35-60 $\mathrm{cm}$ long, densely pubescent, whitish. Flowers first erect, pointing towards tip of the inflorescence (mostly buds), later patent, finally deflexed and appressed to the rachis; opened flowers spreading, up to $1.5 \mathrm{~cm}$ in dia.; rosy or purplish in colour. Bract single, persistent, linear, membranous with distinct midrib, smaller than the longest tepal, up to $5 \mathrm{~mm}$ long, with rosy tinge; bractioles two, linear, with thin papery wing like structure beneath, rosy or purplish. Tepals five, in two whorls, up to $8 \mathrm{~mm}$ long, $1 \mathrm{~mm}$ broad, glabrous, green with rosy to pink tinge, ribbed, margins scarious. Stamens five, filaments fused at base; staminodes fimbriate, alternatively placed with fertile anthers, fused together, rosy-pink-purple in colour, half the length of the filaments; antheriferous filaments and 
lobes rosy-pink when young. Ovary truncate, one celled; style and stigma rosy pink; style $0.4 \mathrm{~cm}$ long, filiform, stigma capitellate. Capsule ca. $5 \mathrm{~mm}$, styles persistent; capsule enclosed with persistent hardened sepals. Seed one, cylindrical, smooth, brown.

Flowering and fruiting: September to March.

Habitat: Found along the road side and canal bunds under the shade, growing in association with Achyranthes aspera L. and Alternanthera sessilis (L.) R. Br. ex. DC., Azadirachta indica Juss., Acacia nilotica (L.) Willd., Jatropha curcas L., Vitex negundo L., Alternanthera sessalis (L.) R. Br. ex. DC., Peristrophe paniculata (Forssk.) Brummit., Cassia tora L., Lantana camara L., Agave americana L. and Cardiospermum helicacabum $\mathrm{L}$.

Distribution: Endemic: Raigad, Amravati, Pune, Sindhudurg and Thane districts in northern Western Ghats of Maharashtra (Mishra \& Singh 2001) and Belgaum District of Karnataka.

Status: Endangered: its distribution in all the reported locations is rare and populations are severely fragmented, which needs immediate attention (Mishra \& Singh 2001). In the present localities only few individuals have been found in Madanabhavi, while fairly good, fragmented populations were observed between Pachapur to Godachimalki villages, along a stretch of nearly $10 \mathrm{~km}$. Most of these populations are along the road sides, while a few are on the canal bunds in the agricultural lands. As both habitats are prone to maximum human interference, the development of conservation strategies for these populations is needed urgently.

Medicinal use: The other species of Achyranthes, especially Achyranthes aspera L. locally known as 'Uttarani' or 'Bili Uttarani' is widely used by local traditional practitioners and Ayurvedic physicians in treating several disorders (Hebbar et al. 2004; Harsha et al. 2004; Upadhya et al. 2009). It was found during the study, that $A$. coynei is also named 'Uttarani' or 'Kempu Uttarani' by the local community who are using it for purposes similar to A. aspera L. Hence it is worthwhile to work on the phytochemical and medicinal investigations of $A$. coynei.

Notes: As pointed out by Santapau, A. coynei is similar in appearance to $A$. aspera var. porphyristachya from which it differs in profusely branched shrubby habit (3.0-3.5 m tall); first erect, later patent, finally deflexed nature of flowers on the inflorescence; opened flowers spreading up to $2.0 \mathrm{~cm}$ in diameter and their rosy-purplish colour (Santapau 1967). However, the diagram and the description of $A$. coynei given by Bhogaonkar \& Devarkar (1999) did not match with Santapau's description. It is interesting to note that all earlier localities of collection (Pune, Raigad, Sindhudurg and Thane, excluding Amravati) fall on or near the same longitude as of the present locality.

\section{REFERENCES}

Almeida, M.R. (1996). Flora of Maharashtra-Vol. 2. St. Xeviers College, Mumbai, 194pp.

Almeida, S.M. (1990). Flora of Savantwadi, MaharashtraVol. 1. Indian Journal of Economic and Taxonomic Botany Additional Series, 351pp.

Bhogaonkar, P.Y. \& V.D. Devarkar (1999). Additions to the flora of Melghat. Some rare and uncommon plants. Technical Bulletin, No. VII. The Directorate, Project Tiger, Melghat, Amravati, 46-47.

Harsha, V.H., S.S. Hebbar, G.R. Hegde \& V. Shripathi (2004). Ethnomedicobotany of Uttara Kannada District, Karnataka State. Bulletin of the Botanical Survey of India 46(1-4): 330-336.

Hebbar, S.S., V.H. Harsha, V.. Shripathi \& G.R. Hegde (2004). Ethnomedicine of Dharwad District in Karnataka, India - plants in oral healthcare. Journal of Ethnopharmacogy 94(2) : 261-266.

Kothari, M.J. \& S. Moorthy (1993). Flora of Raigad District, Maharashtra State-Series 3. Botanical Survey of India, Flora of India, 338pp.

Mishra, D.K. \& N.P. Singh (2001). Endemic and Threatened Flowering Plants of Maharashtra. Botanical Survey of India, Calcutta, 196-197pp.

Phytogeographical distribution of rare, endangered, threatened and endemic taxa of Maharashtra, India (2009). Achyranthes coynei Santapau: Amaranthaceae R. In: ENVIS Centre on floral diversity, BSI, Howrah, WB, India. $\quad<$ http://www.bsienvis.nic.in/RET/maharashtra\%20 index.htm $>$ Downloaded on 10 January 2011.

Raghavan, R.S. \& N.P. Singh (1983). Endemic and Threatened Plants of Western India, pp. 8-11. In: Jain, S.K. \& A.R.K. Sastry (eds.). Plant Conservation Bulletin, Project on the Study, Survey and Conservation of Endangered Flora (POSSCEF). Botanical Survey of India, Calcutta.

Raghavan, R.S. \& N.P. Singh (1984). An inventory of endemic and vulnerable speceis of Western India deserving conservation, Journal of Economic and Taxonomic Botany 5(1): 153-164.

Santapau, H.S.J. (1967). Flora of Khandala on Western Ghats of India. Records of Botanical Survey of India, 224$225 \mathrm{pp}$.

Santapau, H.S.J. (1949). Novitates Bombayenses. Kew 
Bulletin 3(3): 485-492.

Sharma, B. D. \& B. G. Kulkarni (1987). Achyranthes coynei Santapau, Amaranthaceae pp 8-9. In: Nayar, M.P. \& A.R.K. Sastry (eds.) Red Data Book of Indian Plants-Vol 2. Botanical Survey of India, Calcutta.

Sharma, B.D., N.P. Singh, R.S. Raghavan \& U.R. Deshpande (1984). Flora of Karnataka Analysis. Botanical Survey of India, Howrah, 227pp.

Shu, N.X. (2003). Flora of China 5: 424-426pp. <http://flora. huh.harvard.edu/china//PDF/PDF05/Achyranthes.pdf $>$ Downloaded on 01 January 2011

Singh, N.P. \& R.S. Raghavan (1986). Endemic and threatened plants of western India. Ibid 8(1): 34
Singh, N.P., P. Lakshminarasimhan, S. Karthikeyan \& P.V. Prasanna (eds.) (2000). Flora of Maharashtra State Vol2. Botanical Survey of India, Calcutta, India, 777-779pp.

Upadhya, V., D. Mesta, H.V. Hegde, S. Bhat \& S.D. Kholkute (2009). Ethnomedicinal plants of Belgaum region, Karnataka. Journal of Economic and Taxonomic Botany 33(Suppl.): 300-308.

Yadav, S.R. (1997). Flowering plants systematic and diversity, Vol. 1, p.44. In: Pokle, D.S., S.P. Nair \& V.N. Naik (eds.). Proceedings, VII IAAT Annual Meet and National Conference. 